\title{
'n Perspektief op ironie in die hedendaagse Afrikaanse taalgebruik
}

\author{
Truida van der Merwe \\ Departement Afrikaans en Nederlands \\ Universiteit van Stellenbosch \\ STELLENBOSCH \\ E-pos: gsvdm@akad.sun.ac.za
}

\section{Abstract \\ A discussion of irony in contemporary Afrikaans}

The purpose of this article is to investigate the nature of irony as used in contemporary Afrikaans language. A common feature of the irony that shows up consistently in contemporary Afrikaans, is some form of duality or contrast, such as between a reality and a perception. Special attention is given to the distinguishing features of verbal irony and the different semantic contrasts which could occur. Various signals indicating irony, and functions of irony in contemporary use are also examined.

\section{Inleiding}

Die eeue-oue begrip ironie is vandag nog in vele opsigte vaag en daar bestaan 'n magdom verskillende opvattings van wat ironie alles behels (Muecke, 1982:7; Droste, 1959:190). Die redes hiervoor is dat dit moeilik is om iets gemeenskapliks te reduseer uit al die verskillende gedaantes daarvan en dat die begrip nog steeds aan die ontwikkel is. Telkens word nog nuwe manifestasies van ironie as 't ware "ontdek" op vele terreine soos die letterkunde, die filosofie, sielkunde, musiek, skilder- en beeldhoukuns. Hoewel frekwensietoetse nog nie op daaglikse Amerikaanse gesprekke gedoen is nie, is aangetoon dat ' $n$ gemiddelde van vier gevalle van verbale ironie elke halfuur voorkom op populêre, hedendaagse televisieprogramme (Dews \& Winner, 1995:3-19) en een op elke vier bladsye van kontemporêre Amerikaanse literatuur (Kreuz et al.,1996:83-97). 
In die afgelope tyd het talle publikasies verskyn wat ironie uit verskillende perspektiewe probeer karakteriseer het, onder andere pragmatiese, psigologiese, filosofiese en literêre perspektiewe (Lang, 1996:571-586). Vervolgens word ' $n$ kort oorsig gegee van die hoogtepunte in die debat oor verbale ironie.

Volgens die tradisionele beskouing van verbale ironie, wat sy oorsprong in die klassieke retorika gehad het en verder in filosofiese taalbeskouings ontwikkel het, word ironie as 'n stylfiguur beskou wat daarop neerkom dat iets letterliks gestel word, maar waarmee die teenoorgestelde figuurlike waarde bedoel word (Attardo, 2000:797; Sperber \& Wilson 1981: 295). Hiervolgens kan ironie nie onderskei word van ander indirekte taalverskynsels soos die metafoor nie. Die retoriese tradisie, waaraan ontkenning op die een of ander wyse gekoppel word, word tot vandag toe in verskillende gewysigde vorme voortgesit, byvoorbeeld deur Grice (1975; 1989) Searle (1979), Martin (1992) en Giora en Fein (1998). Die eerste radikale alternatief vir hierdie opposisionele model is die pragmatiese teorie van Sperber en Wilson van 1981, wat grondig hersien is in 1992. Hiervolgens is ironie 'n verskeidenheid van "implisiete, herhalende, interpretatiewe gebruike" wat ook die houding van die ironikus ten opsigte van die geïroniseerde te kenne gee. Kreuz en Glucksberg (1989:375-383) het hierby aangesluit met hul beskouing van ironie as 'n "nabootsende herinnering". 'n Ander teorie, wat die fokus probeer skuif het van die uiting na die deelnemers, is ontwikkel deur Clark en Gerrig (1984:121-122). Hulle beskou ironie as 'n soort voorwendsel ("form of pretense") waarmee die ironikus 'n spel van misleiding speel en terselfdertyd sy / haar houding, gevoel of evaluering ten opsigte van die geïroniseerde uitdruk. Die tekortkominge van bogenoemde teorieë is deur verskeie taalkundiges aangetoon, onder andere deur Williams (1984:127-129).

Hierna het ironienavorsers soos Giora (1995) en Clift (1999) die fokus weer laat val op die psigologiese prosesse betrokke by die interpretasie van ironie, asook die verskillende soorte betekenisse wat daarby betrokke is, naamlik "letterlike" en "figuurlike" betekenisse en die interaksie van hierdie betekenisse. Hierdie ironieteorieë is gebaseer op die konsepte van "indirekte ontkenning" ("indirect negation") en "gegradeerde opvallendheid" ("graded salience"). (Hieroor later meer.)

Twee resente opponerende beskouings oor ironie is die volgende:

- Die beskouing dat die proses om ironie te begryp in een fase voltrek word en net so lank duur as by letterlike taalgebruik. 
- Die beskouing dat dit ' $n$ tweefaseproses is waarin die letterlike, niefiguurlike, direkte betekenis van die uitdrukking eerste geprosesseer word en die nie-letterlike, indirekte, figuurlike betekenis eers daarna, en dat dit langer neem om te verstaan as by letterlike taalgebruik (Curcó, 2000:260; Attardo, 2000:810).

Drie verdere teorieë wat die aandag trek, is die spraakhandelingteorie (Amante, 1981; Brown, 1980; Haverkate, 1990 en Glucksberg, 1995), wat ironie as ' $n$ indirekte spraakhandeling beskou, die konstellasieteorie waarvolgens ironie 'n konstellasie van verskynsels is, elkeen met sy eie intrinsieke kenmerke (Anotolli et al., 2000:277) en die ongepastheidsteorie van Attardo (2000:813-824) waarvolgens 'n ironiese uiting kontekstueel onvanpas is.

Myns insiens is hierdie genoemde ironieteorieë geeneen gegrond op omvangryke empiriese ondersoeke oor ironie nie. Dit wil voorkom of teorieë dikwels gebaseer word op enkele voorbeelde, wat dit derhalwe nie geskik daarvoor maak om die groot verskeidenheid ironievorme wat bestaan, voldoende te kan verklaar nie. Verder is talle teorieterme vaag of omstrede.

Vir die doeleindes van hierdie artikel word enkele gevalle van ironie in die alledaagse Afrikaanse taalgebruik ondersoek met die oog daarop om groter duidelikheid te kry oor die semantiese en pragmatiese aard van ironiese uitings. Die volgende punte sal kortliks behandel word:

- Die vergestalting van ironie in alledaagse taalgebruik

- Die semantiese aard van verbale ironie

- Seine ter aanduiding van ironiese taalgebruik

- Pragmatiese aspekte van ironiese woordgebruik

\section{Die vergestalting van ironie in alledaagse taalgebruik}

In alledaagse taalgebruik word dikwels twee ironievorme onderskei, ooreenkomstig die vergestalting van die ironie, naamlik situasionele ironie en verbale ironie (Attardo, 2000:794). Hierdie twee begrippe word vervolgens kortliks onder die loep geneem.

\subsection{Situasionele ironie}

Situasionele ironie het betrekking op 'n situasie waarin die een of ander teenstrydigheid of paradoks voorkom, byvoorbeeld waar 'n brandweerbevelvoerder se huis afbrand as gevolg van nalatigheid terwyl hy besig is met opleiding. Gewoonlik word 'n feit of gebeurtenis eers as ironies geïdentifiseer as dit teen die agtergrond van ander feite beskou word. 
Holdcroft (1983:494) sê in hierdie verband: "a boy falling off a bicycle is not ironic, but the fact that a champion cyclist does may be - and this aesthetic element obviously arises because of discrepancies between expectations and actual performances".

Situasionele ironie kan in woorde uitgedruk of beskryf word, maar moet dan steeds as situasionele ironie beskou word. Dikwels het hierdie soort ironie te doen met 'n bepaalde gebeurtenis, voorval of toedrag van sake wat byvoorbeeld óf tragies óf komies óf tragikomies kan wees.

\section{Voorbeelde:}

- Tragies - soos wanneer ' $n$ jarelange kankerlyer genees word en kort daarna in 'n motorongeluk sterf.

- Komies - soos wanneer 'n mediese praktisyn die van Kerkhoff het.

- Tragikomies - soos wanneer twee fietsryers op 'n donker pad in mekaar vasry, verward opstaan en albei in dieselfde rigtings terugry vanwaar hulle onderskeidelik gekom het, elkeen in die waan dat hy op pad is na sy bestemming.

Situasionele ironie word as 't ware ontdek deur oplettende waarnemers van ironie. Hulle "skep" die ironie uit "rou materiaal" en kondig dit dikwels aan met die gambiet: "Is dit nie ironies dat ...", byvoorbeeld: "Is dit nie ironies dat ons nuwe motor gaan staan en breek het net toe ons ontslae geraak het van ons ou kombi nie?"

Tipiese gevalle van situasionele ironie kom voor

- as daar 'n verskil is tussen die persepsie van 'n situasie en wat in werklikheid die geval is;

- as daar 'n verskil is tussen wat verwag of beoog word en wat uiteindelik realiseer,

- as iets teenstrydig is met die sosiale norme wat vir 'n bepaalde persoon of situasie neergelê is; as iets dus nie gepas, goed en korrek is ten opsigte van dit wat verwag word van die persoon of situasie nie.

Hierdie soort ironie kom dikwels voor in koerantopskrifte om die aandag van die leser te trek, byvoorbeeld: "Lewensredder verdrink"; "Besem en stoffer - beste maats" (buitengewoon lang en kort persoon); "Verbyganger vermoor naby veiligheidswag met oorfone".

\subsection{Verbale ironie}

Verbale ironie is 'n vorm van woordgebruik, wat op so 'n wyse aangewend word dat daar 'n diskrepansie is tussen wat gesê word en wat 
bedoel word, byvoorbeeld: die man sê vir sy vrou: "Ek moet jou een ding ter ere nagee, my skat, geen bakterie sal ooit kan oorleef in die kos wat jy kook nie."

Op die oog af lyk dit na 'n kompliment en kan dit in sommige gevalle ook so verstaan word deur 'n hoorder wat nie die onderliggende waarde kan snap nie, maar in werklikheid is die bedoeling iets heeltemal anders as wat die woorde oënskynlik te kenne gee. Wat op die een vlak geregistreer word en wat bepaalde verwagtings opwek, word op 'n ander vlak gefnuik. Die oënskynlike van die een vlak word op die ander vlak gewysig tot 'n teenoorgestelde waarde.

In 'n geval van verbale ironie soos hierdie word op 'n indirekte wyse gesê wat bedoel word. Hierdie vorm van ironie stem ooreen met ander indirekte taalhandelinge soos suggestie, skimpe en insinuasies.

Hoewel die fokus by verbale ironie val op die woordgebruik en die dualiteit in semantiese waardes wat in die spel is, is verbale ironie nooit heeltemal los te maak van die situasie nie. Dit is soms in 'n mindere en in ander gevalle in 'n meerdere mate veranker in die situasie. By situasie is nie net die gespreksituasie inbegrepe nie, maar ook alle faktore wat met die gespreksituasie saamhang, byvoorbeeld kennis van die spreker, die omgewing, die sosiale struktuur, die politieke agtergrond, die landsomstandighede, ensovoorts. As jy byvoorbeeld sou sê: "Is dit nie 'n lieflike dag nie?" terwyl die wind geweldig onplesierig waai, kan die ironie blyk uit die intonasie van die woorde (veral lieflike), maar is die korrekte interpretasie van die ironie beslis afhanklik van kennis van die spesifieke situasie waarin die uiting funksioneer.

In ironie is daar dus altyd die een of ander kontras teenwoordig, die een of ander diskrepansie wat op 'n indirekte wyse blootgelê word.

Afgesien van bogenoemde klassifikasie van situasionele versus verbale ironie, kan ironie op grond van verskillende ander indelingsbeginsels geklassifiseer word, byvoorbeeld die effek van die ironie op die waarnemer, die medium waardeur ironie uitgedruk word, die tegnieke wat aangelê word, die fokus van die ironie, die funksies van die ironie, ensovoorts. Die verskeidenheid ironievorme is deesdae so groot dat dieselfde ironiese geval verskillend geklassifiseer sou kon word na gelang van die verskillende perspektiewe waaruit dit bekyk word.

Bekende ironievorme in die alledaagse Afrikaanse taalgebruik is komiese ironie, tragiese ironie, dramatiese ironie en Sokratiese ironie. Vervolgens word elkeen kortliks bespreek: 


\section{- Komiese ironie}

Dit is ironie waarby humor en geestigheid in die spel is. Meestal kom komiese ironie daarop neer dat daar 'n skyn van erns is wat eers deurgrond moet word voordat die komiese aard raakgesien kan word (Dikkers, s.j.:31),byvoorbeeld: Die verkeerspolisieman sê vir die spoedoortreder: "Meneer, kan meneer my nie dalk 'n pen leen sodat ek vir meneer 'n kaartjie kan skryf nie?" (Die Huisgenoot, 1999.03.18:102).

\section{- Tragiese ironie / ironie van die noodlot}

Dit is ironie wat baie sterk veranker is in 'n tragiese situasie, byvoorbeeld waar 'n boer sou sê: "Is dit nou nie ironies nie? Verlede jaar het ek die helfte van my skape weens droogte verloor. Vanjaar verloor ek toe die res in die vloedramp." Die volgende koerantopskrif is soortgelyk: "Vrou herstel ná kanker, sterf in ramp" (Die Burger, 1999.09.29:9).

\section{- Dramatiese ironie}

Dit is nog 'n bekende vorm van ironie, wat nie beperk is tot die literêre drama soos sommige mense meen nie, maar ook in die alledaagse lewe voorkom, byvoorbeeld waar iemand iets met geweldige implikasie sê sonder om die betekenisomvang van die woorde te besef, byvoorbeeld: Die premier van Mpumalanga, Mathlangu, het gesê dat politici maar by geleentheid leuens kan vertel.

\section{- Sokratiese ironie}

Hierdie vorm van ironie kom veral in pedagogiese opset voor. Dit het betrekking op argumentasie waarin onkunde geveins word en skynbare dom vrae gevra word om sodoende die gespreksgenoot tot ander insigte te probeer beweeg. Die vraagsteller het nie altyd die volle antwoord op die kwessie nie. Die doel met die vrae is ook soms om die gespreksgenoot van sy / haar selfversekerdheid te laat afsien en te laat insien dat 'n saak verskillende kante het. Hierdie tegniek word dikwels aangewend in alledaagse spreektaal, wanneer ' $n$ ouer die kind iets wil laat insien of indien iemand ' $n$ ander persoon sou probeer oorreed om tot ander politieke insigte te kom deur vrae te vra, byvoorbeeld: Wie het die onafhanklikheid van hierdie land bewerkstellig? Wie het die Republiek tot stand gebring? Wie het die swart man tot beskawing gelei?

\section{Die semantiese aard van verbale ironie}

Twee belangrike kwessies rondom die semantiese aard van ironiese uitings is deesdae ter sprake, naamlik a) die aard van die semantiese verwantskap tussen wat gesê en wat bedoel word en b) die verloop van die interpretasieproses. 


\subsection{Die verband tussen die kontrasterende semantiese waardes van ironie}

\section{Bedoelde betekenis en letterlike waarde}

In baie gevalle van verbale ironie is daar sprake van twee soorte betekenisse, naamlik die betekenis wat 'n mens met die eerste oogopslag aan die ironiese uiting wil heg en die werklike waarde wat die uiting aan die einde van die interpretasieproses verkry. In die ironieliteratuur is nog nie eenstemmigheid bereik oor geskikte terme hiervoor nie. Die meeste ironieskrywers (o.a. Dews \& Winner, 1999:1580) noem die gestelde betekenis van die ironiese woord of uiting die letterlike betekenis en die indirekte waarde die nie-letterlike of figuurlike betekenis. Afgesien daarvan dat daar nie eenstemmigheid heers oor hierdie terme en dit waarop hulle betrekking het nie, is dit myns insiens foutief om aan te neem dat die gestelde oppervlakbetekenis altyd letterlik en die bedoelde betekenis figuurlik is.

Daar is baie ironievoorbeelde, waar die gestelde betekenis 'n figuurlike waarde het en die bedoelde betekenis terugspeel op die letterlike waarde soos in die volgende koerantopskrif: "Russiese boek verkoop soos vloekskoot". (Die verwagte woord in die idiomatiese verbinding is soetkoek in plaas van van vloekskoot, maar laasgenoemde se betekenis "gelukskoot" is versoenbaar met die verbinding se geheelbetekenis. Die verkope was dus goed. Die indirekte waarde wat die ironie hier betrek, is die letterlike waarde van vloek omdat dit 'n vloekwoordeboek is.)

Ook in die volgende geval is die gestelde waarde van dra, wat die ironiese fokus uitmaak, nie die mees "primêre" of "letterlike" semantiese waarde, naamlik "bo die grond hou en van een plek na 'n ander neem" nie (Odendal \& Gouws, $2000^{4}: 172$ ): die bankbestuurder sê vir die kliënt: "Ons het nou meer vir jou gedoen as wat jou eie ma vir jou gedoen het. Ons het jou nou 12 maande lank gedra."

\section{Primêre en sekondêre betekenis}

Bredin (1997:8) gebruik die terme surface en secondary meaning. Die gedagte dat die gestelde semantiese waarde die primêre betekenis by ironie is omdat dit die opvallendste is en die eerste ingesien word en dat die ander waarde wat verskuil is en langer neem om in te sien, sekondêr is, kom ook by Grice (1975:41-58 ) en Giora \& Fein (1998:83-101) voor. Die terme primêre en sekondêre betekenis is dus geskep omdat die twee semantiese waardes betrokke by ironie volgens baie taalkundiges nie tegelykertyd ingesien word nie. Dit is egter myns insiens verwarrende terme omdat dit ook daarop kan dui dat die sogenaamde primêre waarde die hoogste status beklee en die sekondêre waarde van minder belang 
is. Laasgenoemde is volgens my die eintlike semantiese waarde waarom die ironie draai en behoort dus nie as "sekondêr" bestempel te word nie.

Om van ' $\mathrm{n}$ ironiese betekenis of waarde te praat is streng gesproke ook nie korrek nie, omdat dit nie die betekenis van die betrokke woorde is wat ironies is nie, maar die teenstrydigheid tussen taal en bedoeling of tussen die taal en die situasie waarop die ironiese woorde betrekking het.

\section{Geïmpliseerde semantiese waarde}

Grice (1975:58) se term geïmpliseerde semantiese waarde is myns insiens tot dusver die aanneemlikste om die indirekte semantiese waarde kenmerkend van verbale ironie te benoem.

Wat die verband tussen die gestelde oppervlakbetekenis en die geïmpliseerde betekenis by ironie betref, geld die tradisionele opvatting van "teenoorgesteldheid" nog steeds in Afrikaans. Volgens die HAT (Odendal \& Gouws, $2000^{4}: 477$ ) beteken ironie: "Woordgebruik waardeur 'n mens die teenoorgestelde sê van wat jy bedoel", soos in die volgende geval: "Jy is darem vriendelik vandag" (terwyl in werklikheid onvriendelik bedoel word).

\section{Teenoorgestelde betekenis}

Wat in die literatuur presies met "teenoorgestelde" betekenis bedoel word, is nie duidelik nie. Jorgensen et al. (1984:112) sê: "the opposite is a deliberately vague term that can mean either the contrary or the contradictory". Teenoorgesteldheid is ook dikwels vermeng met ander waardes, byvoorbeeld toegeneentheid soos in die volgende ironiese uitdrukkings wat dikwels ten opsigte van jong kinders gebruik word.: "Ou grootman, ..." en "Is hy nie ougat/ ouderwets/ grys nie?" Verdere probleme is dat die "teenoorgestelde" van die werklike waarde nie net op ironie van toepassing is nie, maar ook op ander taalverskynsels soos blatante leuens of op taalgebruik wat uit onkunde spruit. Daar is ook nie in alle gevalle van ironie sprake van 'n "teenoorgestelde" betekenis nie.

\section{Oppervlakwaarde en geïmpliseerde waarde}

Daar is onder die navorsers van ironie wel eenstemmigheid daaroor dat die gewone waarde van die woord of uiting deur ironiese gebruik ontken word, maar wat die aard van die semantiese verhouding is tussen gestelde oppervlakwaarde en die geïmpliseerde waarde, word met verskeie vae woorde soos die volgende aangedui: difference, opposition, contradiction, incompatibility, discrepancy, incongruity en contrariety. 'n Uitspraak hieroor wat die onsekerheid verwoord, is dié van Fogelin (1988:6, 9): 
Sometimes, though I think rarely, in using an ironic utterance we intend the contradictory of what we actually say; sometimes we mean the opposite. In general we imply something incompatible with what we say ... endless variations are possible between the extremes of mere contradiction and the assertion of the complete opposite.

Ook Booth (1974:11) dui die aard van hierdie verhouding in vae terme aan:

[The unstated or implied meanings] will all in some degree be incongruous with what the literal statement seems to say - perhaps even contrary, as one traditional definition put it, but certainly in some sense a retraction, diminution, or undercutting.

\section{Opposisionele ironie en graderingsironie}

Bredin (1997:8-17) bring groter duidelikheid deur 'n onderskeid te tref tussen twee groot kategorieë ironie, naamlik a) opposisionele ironie ("irony of opposition") en b) graderingsironie ("irony of scale"). Wat opposisionele ironie betref, onderskei hy twee ontkenningsmodusse. Eerstens weersprekingsironie ("contradiction"), soos in die uiting "nie te danke nie", wat mense gebruik juis om die dank van iemand te erken. Nog 'n voorbeeld is: Toe, mors nou net weer op die mat! Op letterlike vlak lyk dit na 'n bevel of sterk aanmoediging om wel te mors, maar die werklike bedoeling is dat "jy nie durf mors nie". Dit is dus eerder 'n verbod of dreigement. Ten tweede onderskei hy teenoorgestelde ironie ("contrariety") soos in die geval "Dis nou 'n mooi grap!" (waar die bedoeling meestal die teenoorgestelde is, soos "'n lelike slenter", maar ook 'n ander kontrasterende waarde kan hê, soos "'n groot gemors". Ook Giora en Fein (1998:83-101) reken dat die indirekte ontkenning van ironie meer tussenliggende waardes op die ontkenningsas kan akkommodeer as direkte ontkenning waar net die teenoorgestelde waarde voorkom.

Graderingsironie behels volgens Bredin (1997:12) dié gevalle waar die geïroniseerde taalelement konnotasies het wat gradeerbaar is op 'n skaal van oordrywing aan die een kant tot grade van meiose of litotes aan die ander kant. Volgens hom kan hierdie vorm van ironie later ontwikkel in opposisionele ironie. Hy stel dit soos volg: "Ironies of hyperbole and ironies of meiosis, carried to their extremes, become ironies of opposition" (Bredin, 1997:13). Die volgende is voorbeelde van oordrywing en meiose of litotes onderskeidelik:

- "Jy is darem rojaal vandag!" (gesê teenoor 'n suinige persoon wat teen die verwagting in 'n fooitjie vir 'n kelner los). 
- "Hy is nogal taamlik opgewonde vandag!" (gesê van die werkgewer wie se spanning tot uiting kom in woede-uitbarstings teenoor sy werknemers. Opgewondenheid word meestal geassosieer met uitbundigheid of vrolikheid weens 'n opgewekte gemoedstoestand. Die bekende semantiese waarde van opgewonde word ontken en 'n ander verwante, maar minder bekende waarde, naamlik "gespanne deur oorprikkeling" geld, sodat dit as 'n onderbeklemtoning of "understatement" beskou kan word.)

\section{Semantiese verhoudings van ironie}

Hoewel ironienavorsing tot dusver heelwat lig gewerp het op 'n aantal soorte kontrasterende waardes wat betrokke kan wees by ironiese uitings, is daar nog heelwat semantiese verhoudings wat weinig of geen aandag geniet het nie. Vervolgens word nog 'n paar tipes semantiese verhoudings van ironie met voorbeelde uit hedendaagse Afrikaans geïllustreer.

'n Verskeidenheid polisemiese verhoudings is moontlik. Hoe groter en opvallender die kontras tussen die betrokke semantiese waardes is, hoe treffender is die ironie.

- Daar kan byvoorbeeld 'n diskrepansie wees tussen die bedoelde semantiese waarde en ander interpretasies van 'n leksikale item wat ook tegelykertyd kan geld na gelang van die konteks waarin die uiting voorkom. Die volgende voorbeeld kan as illustrasie dien: "Hy kan baie snaaks wees, hoor!" (grappig, koddig, eienaardig, mallerig, onvriendelik, onbeskof.)

- In die volgende koerantopskrif is die standaardbetekenis en die metaforiese waarde in die spel: "Rokers hoes vanjaar nog R10 per pakkie". Die metaforiese slengwaarde van hoes, naamlik "betaal" kry 'n ironiese waarde in die konteks, wat die letterlike waarde aktiveer.

- Die volgende koerantopskrif draai om metaforiese en idiomatiese waardes: "Gautengse leeus nou lammetjies" (metaforiese spanbenaming leeus en idiomatiese mak lammetjies).

- Die standaard- en dialektiese betekenis kom in die volgende grappie voor: Die vrou vra vir haar huishulp: "Het die dokter toe gesê wat jy makeer?" (wat is verkeerd) Sy antwoord: "Ja, hy het gesê ek makeer nog van die medisyne wat hy laas gegee het" (benodig).

Om die aard van die semantiese verband tussen die kontrasterende waardes te bepaal, is soms moeilik omdat dit nie altyd maklik is om die fokuspunt in die geval van verbale ironie uit die konteks te isoleer nie. Verskillende taalelemente kan in alledaagse taalgebruik die fokus van 
die ironie uitmaak. Die ironie draai byvoorbeeld soms om een leksikale item en in ander gevalle om twee items, 'n woordgroep of 'n sin. Hoe verder 'n mens vorder met ironienavorsing, hoe meer kom 'n mens agter dat ironie hom nie altyd laat vaspen deur bepaalde woorde of uitdrukkings nie. Dit kan selfs lang tekste deurdring op so 'n wyse dat die ironie moeilik aan bepaalde taalelemente gekoppel kan word. In elke geval is daar spanning wat draai om verskillende semantiese waardes. Dit kan later so geyk raak dat die taalgebruiker die ironie nie meer raaksien nie, soos in die volgende voorbeelde:

- Verskoon my asseblief! (Vgl. verskoon met skoon se semantiese waarde(s).)

- lemand afdank. (Vgl. afdank met dank se semantiese waarde.)

- Kan jy vir my die sout aangee? (Die ironie draai om die spraakhandelingverskil tussen die "letterlike" en "figuurlike" waarde - Du Plessis, 1987:208.)

\subsection{Die psigologiese proses wat die snap van ironie voorafgaan}

Volgens Bredin (1997:3) skyn die algemene beskouing te wees dat die gestelde of genoemde semantiese waarde van die ironiese uiting as 't ware in die niet verdwyn nadat die geïmpliseerde waarde ontdek is. Sperber en Wilson (1981:309) kan in dié verband aangehaal word: "implicature carried by an ironical utterance must be substituted for, rather than added to, what was said, because otherwise the total message conveyed would be a contradiction". Dews en Winner (1999: 1582) meen egter tereg dat hierdie opvatting dat die letterlike waarde vervang moet word deur die bedoelde semantiese waarde, omstrede is. Die hoorder moet die letterlike waardes van sommige woorde in die uiting in ag neem om die nie-letterlike waarde te herken. Dit is volgens hulle ook nie altyd so dat 'n figuurlike betekenis van 'n uiting eers via 'n letterlike betekenis afgelei word nie. Die figuurlike betekenis kan 'n konvensionele betekenis wees en taalgebruikers kan 'n nie-letterlike uiting se konvensionele betekenis insien sonder om die letterlike betekenis te analiseer.

Myns insiens lê die aanvang van die proses om by die ironiese waarde uit te kom altyd by die gestelde oppervlakbetekenis van die ironiese uiting, wat nie noodwendig 'n sogenaamde letterlike waarde is nie, maar volgens die verwagting van die leser of hoorder die mees gewone en gebruiklikste waarde is. Die ironiese uiting wek op die oog af die indruk dat dit 'n konvensionele waarde het. Die aanduiding dat hierdie waarde nie in die bepaalde geval geld nie en dat dit "anders" geïnterpreteer moet word, word verkry uit die konteks of omgewing waarin die taalaanbieding 
voorkom. Dit is vir die hoorder of leser 'n verrassing om te ontdek dat die semantiese waarde wat die skrywer of spreker voorgegee het met 'n bepaalde uiting, nie die werklike bedoeling van die skrywer of spreker weergee nie. Dit beteken nie noodwendig dat die waarde wat eerste ingesien is, heeltemal op die agtergrond geskuif word nie. Daar is eerder 'n opweeg van waardes om die verband tussen die opppervlakkige en die werklike waarde vas te stel en om te bepaal wat die rede vir die aktivering van verskillende waardes is.

\section{Seine ter aanduiding van ironiese taalgebruik}

Uit 'n strukturele oogpunt beskou, is ironie gebaseer op 'n sinergie van verskillende kommunikatiewe elemente - verbaal en nie-verbaal. Die probleem vir die hoorder of leser is om die ironie te herken. Gewone taalgebruik is normaalweg nie deurspek met ironie nie. Daar moet dus leidrade vir die hoorder of leser in taalgebruik wees wanneer ironie gebruik word. Ironie kom daarop neer dat 'n bepaalde gedagte op 'n indirekte wyse oorgedra word, maar nie alles wat deel vorm van die ironiese uiting het 'n "anders as normale" of "afwykende" betekenis nie. Vir die waarnemer van ironie is daar gewoonlik 'n paar dinge waarna opgelet kan word om ironiese taalgebruik te herken. Vervolgens word enkele aanduidings van ironie genoem.

\section{Teenstrydigheid tussen waardes van die fokus en gespreksfokus}

Een van die leidrade dat ironie voorkom, lê in die taalgebruik self as die semantiese waardes van die fokus en die gesprekskonteks oënskynlik teenstrydig is, byvoorbeeld: "Daar sit die kat toe pens en pootjies op my tafel. En ek is tog so lief vir katte. Ek klap toe maar my hande en skree om hom daar te verwilder." Hier is die fokuspunt van die ironie geleë in lief. Die omringende sinne dui daarop dat lief nie die gewone semantiese waarde het nie. Die taalkonteks self is dus dikwels 'n aanduiding van ironie.

\section{Negativering of slotvrae}

Die ironikus maak soms van bepaalde taalstrategieë as bykomende middele gebruik, byvoorbeeld negativering of slotvrae soos in die volgende voorbeelde respektiewelik:

- Hy is nou nie juis besonder goed bedeeld met kommunikatiewe vermoëns nie. (Hy is 'n vrot spreker.)

- Sy is mos 'n gesiene inwoner van Stellenbosch, nie waar nie?

Amante (1981: 83) sê dat dit gebiedend noodsaaklik is dat 'n ironikus leidrade gee tot die verstaan van die ironie. 
The clues I am thinking mainly of are: use of some form of the word irony, use of hyperbole, use of understatement or litotes, or other manipulations of the context, such as repetition, so that unmistakable, but unstated, negative meanings may emerge.

\section{Teenstelling tussen woordelikse inhoud en die situasie self}

Die ironikus wat wil verseker dat die ironiese bedoeling begryp word, kies die ironiese woorde gewoonlik versigtig. Die teenstelling tussen die woordelikse inhoud en die situasie is dikwels groot en opvallend, byvoorbeeld wanneer oordrewe en intensiewe vorme soos die volgende gebruik word: "rojaal", "asemrowend betowerend" en "vreeslik oorspronklik".

Die volgende voorbeelde hiervan is Afrikaanse spreekwoorde:

- Die beste stuurlui staan aan wal.

- Elke swart kraai dink sy eier is die witste.

Sosiale, historiese en kulturele agtergrond waarin die ironie voorkom

'n Verdere belangrike aanduiding van ironie is die sosiale, historiese en kulturele agtergrond waarin dit voorkom. Hieroor is skrywers soos Hutcheon (1994:17) en Dews en Winner (1999:1580) dit almal eens. Ook Amante (1981:80) sluit hierby aan met die volgende stelling: "Knowledge of the social system, manners, principles governing conversations, shared background and knowledge of speech acts all contribute to our awareness of irony". En Clark en Gerrig (1984:124) sê: "A listener's understanding of an ironic utterance depends crucially on the common ground he or she believes is shared by the ironist and the audience their mutual beliefs, mutual knowledge, and mutual suppositions" en verder "Listeners must see how the speaker's utterance is relevant to the common ground already established between speaker and addressees. If they cannot, they may not be able to discover the pretense" (p. 125).

Om hierdie siening te illustreer kan die voorbeeld van die koerantopskrif: "Speserye het geen smaak" genoem word. Die leser sal geen ironie daarin ontdek as hy dit nie bekyk teen die agtergrond van die gepaardgaande berig nie. Dit handel oor die Spice girls wat by geleentheid as die swaksgeklede vroue aangewys is.

\section{Mondelinge kommunikasie: ekstralinguale of paralinguale middele}

In mondelinge kommunikasie is spesiale aanduiding van ironie dikwels nodig omdat die persoon tot wie die uiting gerig is, dit vinnig moet snap en die situasie-ondersteuning nie altyd groot is nie. Die ironikus kan dan verskillende ekstralinguale of paralinguale middele gebruik, byvoorbeeld deur 'n vorm van intonasie wat die aandag trek soos 'n ironiese stemtoon 
of 'n nadruklike praatwyse. Navorsing het verskillende kwalitatiewe akoestiese prosesse aangedui wat vir ironiese doeleindes ingespan word. Fónagy (1971), Cutler, (1974), Haverkate, (1990) en Kreuz en Roberts (1995) het byvoorbeeld aangetoon dat sinne soms in die geheel of gedeeltelik genasaleer word om ironie aan te dui. Spraakspoed word soms verlaag, een of meer woorde word beklemtoon of op emfatiese wyse uitgespreek en sillabes word op 'n oordrewe wyse verleng.

Die volgende is byvoorbeeld ' $n$ geval waar intonasie 'n belangrike rol kan speel om homoniem-ironie aan te dui: Prof. Koos gaan ons vandag toespreek.

Fónagy (in: Anolli et al., 2000:276) se ondersoeke het aangetoon dat daar drie stadia van stemproduksie onderskei kan word wanneer ironie uitgedruk word.

... the first characterized by a 'chest-voice' and by a strong laryngeal constriction, with the consequent creak effect; the second qualified by a register change ('head-voice'), with a reduction of energy, a sudden rise in pitch, and a pharyngeal contraction (shrill voice): the third phase, again characterized by a 'chest-voice' a creak, and a low, steady pitch.

Hierdie ondersoeke kan as baanbrekerswerk op hierdie terrein beskou word en behoort verder gevoer te word.

In tersaaklike vakliteratuur bestaan twee teenoorgestelde standpunte van wat die funksie van hierdie paralinguale of "suprasegmentele" middele is. Eerstens is daar diegene wat meen dat hierdie middele 'n teenoorgestelde waarde aandui as wat die ironiese woorde letterlik beteken en dat die ironie as gevolg hiervan begryp word, byvoorbeeld "Jy is 'n genie!" sarkasties verwytend gesê vir 'n persoon wat 'n stommiteit begaan het. Die tweede veronderstelling is dat suprasegmentele kenmerke eerder 'n oordrewe waarde gee aan die letterlike waarde van die ironiese uiting, byvoorbeeld "Jy is 'n genie!" gesê vir 'n persoon, wat normaalweg nie baie vindingryk is nie, wat iets nietigs reggekry het. Dit word as kompliment bedoel, maar met 'n effense spot (Anolli et al., 2000:278). Hierdie twee sienswyses van die funksie van paralinguale middele sluit mekaar nie uit nie, maar kan eerder as komplementêr beskou word.

\section{Lyftaal}

Ironiese uitings kan ook deur vorme van lyftaal herken word, soos 'n vinger wat op die lippe geplaas word, keelskoonmaak, wenkbroue lig, oogknip, elmboogpomp, ensovoorts. Steyn (1975:63) sê in hierdie verband: "Soms kan 'n mens kommentaar lewer deur 'ironies te glimlag' 
of met ' $n$ 'ironiese blik' iemand aan te kyk". Hierdie middele kan byvoorbeeld afsonderlik of in kombinasie gebruik word om die aandag daarop te vestig dat die betrokke taalelemente anders as normaalweg geïnterpreteer moet word.

\section{Spesiale middele in geskrewe taal}

Die gewig wat eksterne faktore dra, verskil van geval tot geval. In die geskrewe taalvorm moet die leser op die teks alleen staatmaak om die ironiese waarde te ontsyfer. Die ironie tree as 't ware self na vore uit die teks. Hier kan ook van spesiale middele gebruik gemaak word om die ironie eksplisiet oor te dra, byvoorbeeld aanhalingstekens, skuinsdruk of vetdruk, byvoorbeeld: "Winnie se klere wys haar 'armoede"" (opskrif Rapport, 1997.10.5:5). (Winnie Mandela het gesê dat sy baie arm is, maar haar kleredrag bewys die teendeel.)

\section{Vereistes vir die snap van ironie}

Die voorafgaande bespreking dui daarop dat dit noodsaaklik is dat die konteks waarin die ironiese uiting voorkom die nodige informasie moet bied om die ware bedoeling van die ironikus bloot te lê. Al sou die konteks egter duidelike seine bevat om op ironie te dui, is dit nog altyd moontlik dat ironie by sommige mense verbygaan of met rampspoedige gevolge verkeerd verstaan word. Om ironie te kan snap moet die ontvanger(s) voldoende kennis of agtergrond hê, 'n fyn taalaanvoeling en 'n sin vir humor. In sommige situasies verskaf dit juis groter trefkrag aan die ironie as sommige lede van die gehoor nie die ironie insien nie, veral as die ironie ten koste van daardie persoon / persone is.

Dit verg ook oplettendheid van die hoorder of leser om hierdie minder gewone, indirekte wyse van taalgebruik korrek te interpreteer. 'n Misverstand soos die volgende kan maklik plaasvind: 'n Manspersoon kan onwetend op ' $n$ meisie se toon trap in 'n samedromming by ' $n$ deur. As sy hom toesnou: "Dit was vreeslik vriendelik van jou!" kan hy dit interpreteer dat sy dankbaar is dat hy haar eerste by die deur laat uitgaan het.

Die spreker en hoorder moet verder dieselfde sentimente deel anders kan bedoelde ironie die hoorder ook maklik ontwyk, byvoorbeeld: as die spreker ironies sê: "Wat 'n lekker dag!" terwyl dit reën, kan die hoorder dit letterlik interpreteer omdat die hoorder van reën hou of omdat die hoorder meen dat die spreker wel van reën hou. 


\section{Pragmatiese aspekte van ironiese woordgebruik}

\subsection{Die funksies van doelbewuste ironiese woordgebruik}

Daar is al baie gegis oor die redes waarom sprekers of skrywers dit nodig vind om hul bedoeling op ' $n$ ingewikkelde, indirekte, teenstrydige wyse te kenne te gee. Vervolgens word enkele funksies van ironie in die hedendaagse Afrikaanse taalgebruik aan die hand van voorbeelde behandel.

Ironie word dikwels gebruik om op 'n indirekte wyse die houding of gevoel van die ironikus teenoor hom- of haarself, iemand anders of iets uit te druk of om 'n oordeel oor iets te vel. Daar word dikwels gepraat van die slagoffer(s) of teiken van ironie. Dit kan dus die ironikus self wees, die hoorder(s) of 'n gedeelte van die gehoor, 'n persoon of persone buite die gespreksverband, 'n voorwerp, saak, of abstrakte aangeleenthede soos sosiale en politieke kwessies. Die moontlike fokuspunte is legio.

\section{Voorbeelde:}

- Hulle is sulke liewe mense (spreker gee 'n negatiewe gevoel te kenne).

- Ek is nou so bly dit reën - my wasgoed is pas op die draad (misnoegdheid).

Verskeie skrywers het hulle hieroor uitgelaat, onder andere Grice (1989:53), Attardo (2000:817) en Dews en Winner (1999:1580). Laasgenoemdes meen dat ironiese kritiek wat op 'n positiewe wyse gestel word, die meeste voorkom. "The most commonly used form of irony is one in which the speaker says something positive to convey a negative attitude" (Dews \& Winner, 1999:1580).

\section{Sarkastiese en vriendelike ironie}

'n Perspektief op ironie wat volgens Anolli et al. (2000:275-278) deesdae baie prominensie geniet, is die onderskeid tussen sarkastiese ironie wat verwant is aan beskuldiging aan die een kant en vriendelike ironie, wat weer verwant is aan lofprysing aan die ander kant.

Sarkastiese ironie word volgens Jorgensen $(1996: 615,627)$ baie algemeen in alledaagse gesprekke onder intieme kennisse gebruik om te kritiseer, te kla en misnoeë uit te spreek, veral oor kleinerige misstappies of foutjies. Die indirektheid van die sarkastiese ironie skep 'n bietjie onsekerheid oor hoe die spreker presies geïnterpreteer moet word, distansieer hom van die inhoud van sy woorde, stel hom in staat om die verantwoordelikheid vir die potensieel skadelike interpretasie van sy 
uiting te vermy en stel hom in 'n meer positiewe lig as by direkte aanvalle en beskuldigings. 'n Indirekte opmerking hoef nie so ernstig vertolk te word nie, want dit lê nie so 'n direkte verpligting op die hoorder nie. Barbe (1995:171) lê soveel klem op hierdie pragmatiese aspek van ironie, dat sy ironie definieer as "a critical face-saving attitude for both speaker and listener".

Vriendelike ironie, aan die ander kant, word minder dikwels aangetref as sarkastiese ironie. Dit neem meestal die vorm aan van 'n oënskynlik onvriendelike opmerking wat positief bedoel word. Dit kan byvoorbeeld gebruik word om spottend af te keur wat jy in werklikheid prys. So is daar byvoorbeeld die bekende uitdrukking wat sommige Afrikaanssprekendes gebruik as wenk aan 'n gasvrou om nog meer van 'n gereg of lekkerny aan te bied omdat dit lekker smaak: Dit smaak na teer (ek lus nog meer).

Sommige taalkundiges reken dat vriendelike ironie slegs met welslae gebruik kan word indien dit direk uit 'n vorige uiting aanhaal (Anolli et al., 2000:278). Hierdie veronderstelling is myns insiens nie korrek nie. Die volgende voorbeelde bewys die teendeel:

- "Jammer om jou aanhou te pla" (as aanhoudend blomme afgelewer word weens 'n verjaardag).

- "Jy het dit darem swaar in die lewe" (as 'n persoon 'n oorsese vakansie as prys gewen het).

- "Wat 'n mislukking!" (as 'n mislukking verwag is, maar 'n reusesukses behaal is).

'n Rede waarom positiewe ironie minder voorkom as negatiewe ironie is dat dit gevaarlik is om iets negatiefs te sê met 'n positiewe bedoeling. 'n Misverstand kan groot negatiewe implikasies hê.

\section{Ironie as beklemtoning}

'n Ander funksie van ironie is om iets te beklemtoon. 'n Ironiese uiting verleen in baie gevalle meer beklemtoning as 'n gewone uiting. Hierdie siening word ondersteun deur Kaufer (1983: 453) wat die volgende sê: "Specifically, it permits a speaker to emphasize a particular proposition by pretending to contradict it".

\section{Ironie word op 'n dubbele gehoor gerig}

Waarskynlik spruit ironie ook soms uit die begeerte om af te wyk van die afgesaagde, gewone segswyses en om skerpheid te verleen aan kommunikasie. Soms is dit selfs ' $n$ kode tussen intelligente persone om minder skerp persone uit te sluit uit 'n opmerking. In hierdie verband kan Fowler (1965:303-306) se definisie van ironie aangehaal word wat 
daarop dui dat ironie op 'n dubbele gehoor gerig word - die intelligentes of ingewydes aan die een kant en die onintelligentes aan die ander kant.

Irony is a form of utterance that postulates a double audience, consisting of one party that hearing shall hear and shall not understand, and another party that, when more is meant than meets the ear, is aware both of that more and of the outsiders' incomprehension. [It] may be defined as the use of words intended to convey one meaning to the uninitiated part of the audience and another to the initiated, the delight of it lying in the secret intimicy set up between the latter and the speaker.

\section{Ironie as humor of spot}

Ironie word verder ook dikwels om humoristiese redes ingespan. Dit word gebruik om te spot en te terg. Die WAT (Schoonees, 1972, Deel IV:692) beklemtoon hierdie funksie van ironie in sy definisie wat deels soos volg lui: "Dit is spotspraak of bedekte spot / skerts" en verduidelik verder dat dit daarom gaan "dat jy spottend prys wat jy in werklikheid afkeur en andersom". So kan daar byvoorbeeld gespot word deur vir 'n gespreksgenoot te sê: "Ek sien jy het ook gaan luister na die opwindende toespraak" (as die toespraak vervelig was). Ironie met humor hou verskillende voordele in. Dit kan byvoorbeeld aangewend word om na 'n informeler, speelse styl oor te skakel of gespanne situasies te ontlont. Dit is egter nie net op hierdie wyse dat spot met behulp van ironie uitgedruk word nie. Daar word nie net gespot soos die WAT dit stel deur "prys" en "afkeur" nie, maar op talle ander wyses. Teenoorgesteldheid in ander verbande is ook dikwels ter sprake by ironiese spot, byvoorbeeld verskillende vorme van litotes soos in die volgende gevalle:

- "Ag moedertjie, kyk tog sy ou voetjies!" (gesê vir 'n reus met groot voete met die naam van Tiny).

- Sy is nou nie juis mooi nie, maar tog so dierbaar (sy is lelik).

- In die volgende geval lê die kontras van semantiese waardes daarin dat 'n woord buite sy normale verband toegepas word: Die ironikus sê byvoorbeeld vir 'n persoon wat struikel: "Jy is darem vlugvoetig, hoor!" Hoewel die woord vlugvoetig gepas is met betrekking tot balansherstelbewegings, is dit hier ironies, omdat dit normaalweg dui op die voetvaardigheid van 'n danser.

- Nog 'n voorbeeld waar geen sprake van "teenoorgesteldheid" is nie, maar waar die verbale ironie spottend op die situasie gegrond is, word aangetref wanneer twee vroue, wat toevallig dieselfde rok aanhet, vir mekaar sê: "Jy het 'n pragtige rok aan". 


\section{Ironie as wrang spot}

Sommige vorme van ironie slaan oor na ietwat wrange spot. Uitings soos die volgende lyk oënskynlik onskuldig, maar kan 'n stekie bevat:

- "Sy het al die fatsoenlike mense met haar bikini geskok" (hulle gee voor dat hulle fatsoenlik, preuts of konserwatief is).

- "Onthou, Jan is 'n geleerde man" (as Jan effens gefouteer het).

Dieselfde ironiese uiting kan in verskillende situasies aangewend word om verskillende spraakhandelinge uit te voer, byvoorbeeld om te beskuldig, te prys, te spot, ensovoorts. Hierdie funksionele waardes vorm deel van die semantiese eienskappe van ironie, byvoorbeeld: "Jy is darem dapper, hoor!"

So 'n uiting kan in verskillende situasies gebruik word, byvoorbeeld:

- Teenoor iemand wat botweg weier om 'n bobbejaanspinnekop van die leeslamp te verwyder (dapper met die teenoorgestelde bedoeling, naamlik "lafhartig").

- Teenoor 'n oënskynlik onverskrokke jongman wat sy suster laataand stuur om te reageer op die voordeurklokkie (dapper met die bedoeling van "minder dapper as wat jy voorgee / as wat van jou verwag word / as wat ek gedink het jy is", ens.).

- Van 'n motoris wat 'n vragmotor teen $180 \mathrm{~km}$. per uur teen 'n bergpas verbysteek (dapper met die bedoeling van "onverskillig" of "roekeloos").

\subsection{Doelbewuste versus onbewuste aanwending van ironie}

Ironie word waarskynlik meestal doelbewus geskep om redes wat reeds aangetoon is. Nie alle vorme van verbale ironie word egter doelbewus deur ' $n$ ironikus geskep nie. Sommige ironiese uitings kom tot stand as gevolg van ondeurdagte woordgebruik, of woordgebruik wat voortspruit uit onkunde.

Onkunde kan aanleiding gee tot 'n ironiese uiting wanneer 'n spreker onwetend iets sê wat die teenoorgestelde uitdruk van wat werklik die geval is of was. Dit is dan net vir die waarnemer wat vertroud is met die agtergrond, ironies, byvoorbeeld: "Johan Roux is die beste wynproewer van hierdie maatskappy" (terwyl sommige hoorders weet dat Johan nie alleen 'n goeie beoordelaar is nie, maar dat hy ook by tye te diep in die bottel kyk). 
Ondeurdagte ironiese woordgebruik het betrekking op 'n uiting van 'n spreker met slegs een bepaalde interpretasie daarvan in gedagte, maar wat dubbelsinnig blyk te wees wanneer die hoorder(s) 'n ander (dikwels komiese) waarde ontdek wat tegelykertyd in die bepaalde situasie van toepassing kan wees. Hierdie tipe ironie kan met die volgende voorbeeld toegelig word: 'n Aankondiging word vir 'n groep studente gemaak met die bedoeling om hulle in kennis te stel dat die professor wat vir hulle moet klas gee, laat sal wees. Die mededeling lui soos volg: "Professor Joubert is vanmôre 'n bietjie vertraag". Uit die gelag wat hierop volg, blyk dit dat die studente nie net die bedoelde semantiese waarde van vertraag, naamlik "laat", in die situasie wil laat geld nie, maar terselfdertyd ook die waarde "swaksinnig / gestrem".

\section{Slotbeskouing}

Ironie kom in alledaagse taalgebruik in 'n groot verskeidenheid vorme voor. Op grond van die feit dat daar by ironie altyd 'n dualiteit van semantiese waardes in die spel is, wat op 'n indirekte wyse in kontras teenoor mekaar staan, is dit meestal die meer intelligente taalgebruiker wat gestalte gee aan ironie of dit snap. Nogtans durf die rol daarvan in die alledaagse taalgebruik nie onderskat word nie.

\section{Bibliografie}

Amante, D.J. 1981. The theory of ironic speech acts. Poetics Today, 2(2):77-96.

Anolli, L., Ciceri, R. \& Infantino, M.G. 2000. Irony as a game of implicitness: Acoustic profiles of ironic communication. Journal of Psycholinguistic Research, 29(3): 275-311.

Attardo, S. 2000. Irony as relevant inappropriateness. Journal of Pragmatics, 32:793826.

Barbe, K. 1995. Irony in context. Amsterdam : Benjamins.

Booth, W.C. 1974. A rhetoric of irony. Chicago : University of Chicago Press.

Bredin, H. 1997. The semantic structure of verbal irony. Journal of Literary Semantics, XXV1(1):3-20.

Brown, R.J.L. 1980. The pragmatics of verbal irony. In: Shuy, R.W. \& Shnukal, A. (eds.) Language use and the uses of language. Washington DC : Georgetown University Press. p. 111-127.

Clark, H.H. \& Gerrig, R.J. 1984. On the pretense theory of irony. Journal of Experimental Psychology: General, 113(1):121-126.

Clift, R. 1999. Irony in conversation. Language in Society, 28(4):523-553.

Curcó, C. 2000. Irony: Negation, echo and metarepresentation. Lingua, 110(4):257280.

Cutler, A. 1974. On saying what you mean without meaning what you say. In: LaGaly, M.W., Fox, R.A., \& Bruck, A. (eds.) Papers from the Tenth Regional Meeting, Chicago Linguistic Society. Chicago : Chicago Linguistic Society. p. 117-127.

Dews, S. \& Winner, E. 1995. Muting the meaning; a social function of irony. Metaphor and Symbolic Activity, 10:3-19. 
Dews, S. \& Winner, E. 1999. Obligatory processing of literal and nonliteral meanings in verbal irony. Journal of Pragmatics, 31:1579-1599.

Dikkers, S. s.j. Ironie als vorm van communicatie. Den Haag : Kruseman.

Droste, F.G. 1959. De semantische structuur van de ironie. Algemeen Nederlands Tijdschrift voor Wijsbegeerte en Psychologie, 51:190-204.

Du Plessis, L.T. 1987. Dis net 'n grappie! Ironie: 'n perspektief binne die Taalhandelingsteorie. In: Van Jaarsveld, G.J. (red.) Wat bedoel jy? Pretoria : Serva-uitgewers. p. 195-215.

Fogelin, R.J. 1988. Figuratively speaking. New Haven \& London : Yale University Press.

Fónagy, I. 1971. The functions of vocal style. Literary style. A symposium. New York : Oxford University Press. p. 159-174.

Fowler, H.W. 1965. A dictionary of modern English usage. Oxford : Clarendon.

Giora, R. 1995. On irony and negation. Discourse Processes, 19:239-264.

Giora, R. \& Fein, O. 1998. Irony: Graded salience and indirect negation. Metaphor and Symbol, 13:83-101.

Glucksberg, S. 1995. Commentary on nonliteral language: Processing and use. Metaphor and Symbolic Activity, 10(1):47-57.

Grice, H.P. 1975. Logic and conversation. In: Cole, P. \& Morgan, J.L. (eds.) Syntax and semantics. Volume 3. Speech acts. New York: Academic Press. p. 41-58.

Grice, H.P. 1989. Studies in the way of words. Cambridge, MA : Harvard University Press.

Haverkate, H. 1990. A speech act analysis of irony. Journal of Pragmatics, 14(1):77109.

Holdcroft, D. 1983. Irony as a trope, and irony as discourse. Poetics Today, 4(3):493512.

Hutcheon, L. 1994. Irony's edge. The theory and politics of irony. London : Routledge.

Jorgensen, J. 1996. The functions of sarcastic irony in speech. Journal of Pragmatics, 26:615-634.

Jorgensen, J., Miller, G.A. \& Sperber, D. 1984. Test of the mention theory of irony. Journal of Experimental Psychology: General, 113(1):112-120.

Kaufer, D.S. 1983. Irony, interpretive form and the theory of meaning. Poetics Today, 4(3):451-464.

Kreuz, R. \& Glucksberg, S. 1989. How to be sarcastic: The echoic reminder theory of verbal irony. Journal of Experimental Psychology: General, 118(4):374-386.

Kreuz, R.J. \& Roberts, R.M. 1995. Two cues for verbal irony: Hyperbole and the ironic tone of voice. Metaphor and Symbolic Activity, 10:21-31.

Kreuz, R.J., Roberts, R.M., Johnson, B.K. \& Bertus, E.L. 1996. Figurative language occurrence and co-occurrence in contemporary literature. In: Kreuz, R.J. \& MacNealy, M.S. (eds.) Empirical approaches to literature and aesthetics. Norwood, NJ : Ablex. p. 83-97.

Lang, B. 1996. The limits of irony. New Literary History. A Journal of Theory and Interpretation, 27(2):571-588.

Martin, R. 1992. Irony and universe of belief. Lingua, 87:77-90.

Muecke, D.C. $1982^{2}$. Irony and the ironic. London : Methuen.

Odendal, F.F. \& Gouws, R.H. (reds.) $2000^{4}$. Verklarende Handwoordeboek van die

Afrikaanse Taal. Midrand : Perskor.

Schoonees, P.C. (hoofredakteur). 1972. Woordeboek van die Afrikaanse Taal. (WAT) Pretoria : Die Staatsdrukker.

Searle, J. 1979. Expression and meaning. Cambridge : Cambridge University Press. 
Sperber, D. \& Wilson, D. 1981. Irony and the use-mention distinction. In: Cole, P. (ed.) Radical pragmatics. New York : Academic Press. p. 295-318.

Sperber, D. \& Wilson, D. 1992. On verbal irony. Lingua, 87:53-76.

Steyn, J.C. 1975. Taalkundige grondslae van 'n paar soorte ironie. In: Van Rensburg, F.I.J. (red.) Die kunswerk as taal. Kaapstad : Tafelberg. p. 34-68.

Williams, J.P. 1984. Does mention (or pretense) exhaust the concept of irony? Journal of Experimental Psychology: General, 113(1):127-129.

\section{Kernbegrippe:}

geïmpliseerde semantiese waarde

graderingsironie

ironie

opposisionele ironie

situasionele ironie

verbale ironie

Key concepts:

implicature

irony

irony of opposition

irony of scale

situational irony

verbal irony 